\title{
Cultural Diversity, European Public Policy Exception and Family Law of Muslim Countries
}

\author{
Gloria Esteban de la Rosa \\ University of Jaén, Jaén, Spain \\ Email: gesteban@ujaen.es
}

Received 28 April 2015; accepted 8 June 2015; published 11 June 2015

Copyright (C) 2015 by author and Scientific Research Publishing Inc.

This work is licensed under the Creative Commons Attribution International License (CC BY). http://creativecommons.org/licenses/by/4.0/

(c) (i) Open Access

\section{Abstract}

The recognition of cultural diversity as a value of the European Union Law is undoubtedly present in the current process of integration, which, in turn, is related to the maintenance of peace. Without prejudice to the treatment given by national regulations (Private International Law systems) of each Member State to the issue of cultural diversity existing in the current European society, it may be mentioned the positioning that has also been taken by the EU legislature of PIL on the treatment of said diversity. Tools used by the Private International Law system both for European Union Member States and for the European Private International Law system itself to give answers to this multiculturalism located in the territory that comprises the European Union Member States are discussed below. In particular, art. 10 of the Council Regulation (EU) no. 1259/2010, of 20 December 2010, implementing enhanced cooperation in the area of the law applicable to divorce and legal separation. This exception (public policy) will be practically operational in general when it comes to the implementation of the national system of an Islamic countries, because it may be considered that there is a difference between men and women in everything related to family relationships. The aim of this paper is to analyze the possibility of the "recognition method" as a clause for the interpretation of Private International Law to permit the application of foreign Muslim Law by European authorities in family cases and to avoid limping relationships.

\section{Keywords}

Cultural Diversity, Muslim Law, Moroccan Family Law, Public Policy Exception, Divorce (Talaq, Tatliq), Dowry, European Private International Law, Recognition Method, Case Law, Member States, European Union 


\section{Introduction}

The current international community can be defined as an overcoming notion of the traditional "international society", to the extent that there is place in it for values that are the hallmarks of mankind and, particular cultural diversity, which can be considered a value of every society that is considered advanced and, in particular, constituted by States that are members of the European Union (Carrillo Salcedo, 2005). On the other hand, it is important not to lose sight of the necessarily multicultural nature of the EU, since these are countries comprising a plurality of people of different provenance and origin.

It can be said that the current European Union regulations recognize cultural diversity as a value of society in line with the UNESCO Declaration of November 2, 2001. And in this sense, a number of policy instruments can be cited as having been adopted by European Union institutions for managing the diversity of cultures and the recognition of that diversity. In this regard, it includes the European agenda for Culture in a globalizing world [Communication from the Commission to the European Parliament, the Council, the European Economic and Social Committee and the Committee of the Regions, on "A European agenda for culture in a globalizing world", Brussels, 10.05.2007, COM (2007 242 final; SEC (2007) 570], and the plurality of times when European Union institutions have conducted demonstrations in favour of Intercultural Dialogue.

It should be specially highlighted the year 2008 that has been considered the European Year of Intercultural Dialogue, in order to give expression and visibility to the best practices and processes of Intercultural Dialogue, so as to establish a sustainable strategy beyond 2008 [Decision No. 1983/2006/EC of the European Parliament and of the Council of December 18, 2006 (OJ, L Series, no. 412 of 30.12.2006)].

In 2010, the European Union Commission prepared a Report (for the European Parliament, the Council, the European Economic and Social Committee, and the Committee of the Regions), on the implementation of the European Agenda for Culture [COM (2010) 390 final, prepared in Brussels on July 19, 2010; SEC (2010) 904]. As stated in the said report, "culture lies at the heart of the European project and is the anchor on which the European Union's 'unity in diversity' is founded. The combination of respect for cultural diversity and the ability to unite around shared values has guaranteed the peace, prosperity and solidarity the EU enjoys. In today's globalising world, culture can make a unique contribution to a European Strategy for smart, sustainable and inclusive growth, promoting stability, mutual understanding and cooperation worldwide" (see introduction).

Therefore, the recognition of cultural diversity as a value of the European Union regulations is undoubtedly present in the current process of integration, which, in turn, is related to the maintenance of peace. On the other hand, in any case, it is a responsibility shared with the Member States and, finally, it has a plurality of statements, among which are of special interest among which private international situations are of special interest and, therefore, the receptivity of European Private international Law to the value of cultural diversity (assumption of creation of multicultural societies).

\section{Notions of Culture and Cultural Diversity}

It is not easy to define what is meant by cultural diversity (Regeiro García \& Pérez Álvarez, 2014), to the extent that it should not be considered that there is one single notion, applicable in all cases, regardless of the particular field in which it is used or coined (Petit, 2012). Therefore, it is based on the notion of cultural diversity (directly related to the idea of multiculturalism) which is used by the UNESCO Convention on the Protection and Promotion of the Diversity of Cultural Expressions of March 18, 2007. According to Art. 4, 1, cultural diversity refers to "the 'manifold ways in which the cultures of groups and societies find expression'. These expressions are passed on within and among groups and societies".

On November 2, 2001, at the 31st Conference of UNESCO, the Universal Declaration on Cultural Diversity had previously been adopted, whose Art. 1 states that cultural diversity is the common heritage of mankind. Furthermore, cultural diversity widens the range of options open to everyone; it is one of the roots of development, understood not simply in terms of economic growth, but also as a means to achieve a satisfactory intellectual, emotional, moral and spiritual existence (Art. 3). And finally, it notes that the defence of cultural diversity is an ethical imperative, inseparable from respect for the dignity of the human person (Art. 4).

Firstly, as stated in the field of anthropology, cultural identity and diversity are not isomorphic notions, i.e. they do not crystallize together. And secondly, the idea of multiculturalism can also be understood differently, not only from the point of view of the theory-policy, but also according to the particular scope of the regulations in which it is used. And, specifically, when it comes to private international law, cultural diversity and identity 
can be safeguarded differently, several proposals having been raised by the doctrine in this sense, both Spanish (Abarca Junco, 2000; Quiñones Escámez, 1999; Rodríguez Benot, 2002) and foreign (Jayme, 1992).

\section{Treatment of Cultural Diversity in Private International Law, in Particular in the European Union Legislation and in Case Law of Member States}

\subsection{Presentation}

Based on the concept of multiculturalism that matters for purposes of the Law and, in particular, of the Private International Law (PIL), it would be interesting to verify the treatment it receives from the perspective of EU regulations and in particular, in the most recent EU instruments. Records used by the PIL system both for EU Member States and for the European PIL system itself to give answers to this multiculturalism located in the territory that comprises the EU Member States are discussed below.

However, the presence of a multicultural society in the EU is not simultaneously a unitary reality; it has a plurality of expressions, which, in turn, have been taken into account by the Private International Law system of each one of the Member States (Combalía, Diago Diago, \& González Varas, 2011). In principle, the answers given by each Private International Law system of the Member States to the presence of nationals of third States in their respective territories was to reform the PIL systems in order to vary the criterion of nationality as a connection point of the conflict rule, stating instead, the usual place of residence (Gardeñes Santiago, 2012).

This would thus ensure that personal and family relationships of foreigners residing in an EU Member State are regulated in accordance with the law of that State, which speeds solving issues on the one hand and, on the other hand it prevents the application of foreign regulations that are considered incompatible with public policy. This has been the case in several EU Member States, in particular, France and Belgium, among others, but also in Spain, because as it is known, the amendment of Art. 107 of the Civil Code by means of LO 11/2003 (Organic Law, by its Spanish abbreviature), which took place as an urgent measure in order to prevent the problems and shortcomings that were occurring for its application to cases of couples of Moroccan nationality (Abarca Junco, 2005; Adam Muñoz, 2004).

Such reform has been accompanied by the inclusion in the cited Art. 107 of a new paragraph which includes an extension of the rule that allows the application of the Spanish law when a number of circumstances occur. The application of national common law of the spouse as the first connection criterion is maintained, but it is accompanied by an extension of the rule that, in practice, has worked as a general rule and the rule of conflict as an exception. Thus, it has allowed the Spanish judicial authorities to discontinue the application of the content of the Moroccan Family Law, given its prospective incompatibility with public policy, and instead, to dissolve the marriage according to the law of the forum (Esteban, Ouald Ali, \& Saghir, 2007).

Contributions of the doctrine on the receipt of the modifications made in some of these countries with Islamic traditions in European Law have become very frequent (Quiñones Escámez, 2004). Such changes have been intended to allow the application of Law in these countries by the European authorities, considering that the current wording of some of its provisions, for example, the Moroccan Family Code 2004, is not inconsistent with international public policy (Esteban de la Rosa \& Saghir, 2009). This is how the reform that has taken place in Morocco can be considered, specifically in relation with the forms of dissolution of marriage, which makes it no longer necessary to apply Art. 107 of the Spanish Civil Code after its reform by the OL 11/2003, as there are new ways to dissolve a marriage which are not inconsistent with Spanish public policy.

It should be noted, on the other hand, that the application of Muslim family law is personal in nature, i.e. it binds Muslims despite not residing in the country of their nationality. It is a kind of protection of the national law to all its nationals residing abroad (Foblets \& Carlier, 2005).

\subsection{Cultural Diversity and European Private International Law: Art. 10 of Council Regulation 1259/2010}

Without prejudice to the treatment given by national regulations (Private International Law systems) of each Member State to the issue of cultural diversity existing in the current European society, it may be mentioned the positioning that has also been taken by the EU legislature of PIL on the treatment of said diversity, for example Art. 10 of the Council Regulation 1259/2010 of 20 December 2010, implementing enhanced cooperation in the area of the law applicable to divorce and legal separation (OJ, L Series, no. 343 of December 29, 2010). 
The said provision points that: "Application of the law of the forum. Where the law applicable pursuant to Article 5 or Article 8 makes no provision for divorce or does not grant one of the spouses equal access to divorce or legal separation on grounds of their sex, the law of the forum shall apply". This exception (public policy) will be practically operational in general when it comes to the implementation of the national system of an Islamic countries, because it may be considered that there is a difference between men and women in everything related to family relationships, as it has already been highlighted by jurisprudence of the Court of Cassation in relation to petitions for dissolution of marriage filed by nationals of countries with which France has a Convention (Algeria, Morocco) (Monéger, 2014). In such cases, it is considered that such regulations do not allow access to the dissolution of marriage to men and women on equal terms.

It is stated that the said Art. 10 is directed, specifically, to married couples of Muslim origin, not allowing the application of foreign regulations when there is no dissolution of marriage or when it is more burdensome for one of the spouses (Gruber, 2012). On the other hand, it is a provision that, although inserted within a rule of EU origin, has been widely criticized. It is considered a true innovation of the European PIL system, because it does not allow public policy to fulfil its function through the analysis of a particular outcome caused in a particular case by the application of foreign Law, and it makes a judgement in the abstract of his incompatibility with public policy.

In fact, it is considered different from the classical ordre public exception that is regulated in Art. 12 of the Regulation ("Public policy. Application of a provision of the law designated by virtue of this Regulation may be refused only if such application is manifestly incompatible with the public policy of the forum").

Therefore, Art. 10 of Rome III Regulation does not allow public policy to fulfil its function and the specific circumstances of the case to be analysed, as it happens for example in German jurisprudence, in particular, the judgement of the OLG (Higher Regional Court of Appeals) of Munich, dated September 19, 1988, considering that the divorce requested by the spouses is not incompatible in accordance with their national law (unilateral repudiation), to the extent that it has been accepted by the wife and, on the other hand, this form of dissolution of marriage exists in the German legislation (Jayme, 1989).

The decisions of the OLG of Hamburg, dated May 21, 2003 and of the OLK of Koblenz, on September 19, 2012 are also of interest. In them, there was discussion on the petition for "dissolution of marriage in exchange for compensation" or the woman foregoing something. Specifically, there was discussion of the possibility of the woman to forego the dowry, in exchange for the dissolution of the marriage. This was not considered incompatible with public policy (Weller, 2014).

German case law has considered that in such cases, a reduction in the dowry in this mode of dissolution of marriage is in order, as it is not deemed incompatible with public policy. However, the doctrine understands that this form of dissolution of marriage is discriminatory, because it is only provided for the case of women and, therefore, it is not admissible in accordance with Art. 10 of the Rome III Regulation, which also prevents the use of the "theory of data" ("datum theory") (Weller, 2014).

In any case, Art. 10 of the Rome III Regulation leads to an abstract control on the compatibility with the public policy of foreign law applicable to divorce (Weller, 2014). The European legislature did not want the Islamic sharia Law to be applied (Gruber, 2012). In these cases, the possibility of a teleological reduction of the rule is proposed, in such a way that it can be considered that the regulation is not inconsistent with public order, if the woman accepts the divorce (Helms, 2014).

Lastly, it is of interest to analyse its substantive scope, that is, the issues that fall under this new rule of the (European) Community system of Private International Law, in so far as it has also been discussed (Winkler v. Mohrenfels, Zeitschrift für Europäisches Privatrecht, 2013, 699 ff). Reference should be made to the critic made by the doctrine of the poor values of the PIL and to the fact that at present cultural diversity is also a value for the PIL.

\section{Case Law of the Member States}

\subsection{Implementation of the Moroccan Family Code and the Principle of Equality}

We can quote judgements pronounced by the authorities of the EU in the field of Private International Law, which have also specifically solved issues which are increasingly frequently raised, where the element or "cultural factor" is present. In this sense, the pronouncements of judicial authorities of the EU Member States on matters where the stakes the application of a foreign system of Islamic tradition is at stake, begin to be signifi- 
cant, not only numerically, but also qualitatively. However, the establishments that have generated most interest were undoubtedly polygamy and repudiation, being these, at least in appearance, most likely to be incompatible with public policy (Checa Martínez, 2011; Ortiz Vidal, 2014).

And, specifically, knowing whether the current regulation of dissolution of marriage in the mentioned FC (Esteban de la Rosa, 2009; Esteban de la Rosa, 2010; Ouhida, 2009) is incompatible with public policy is an issue that generates interest, as it contravenes the principle of equality between men and women, by providing different procedures for the dissolution of marriage for each (Esteban de la Rosa, 2014a; Esteban \& Saghir, 2010). And, specifically, in the case of dissolution under judicial supervision, case law indicates that equality is not granted in the access (to man and woman) to the above dissolution (Ouald Ali, 2011).

And in this sense, we may quote two judgements of the Court of Cassation, of October 23, 2013 (no. 1225802 and 12-21344), commented by the doctrine (Monéger, 2014), criticizing the position held by the High Court, which considers that the dissolution of marriage under judicial control that is included in both the new Moroccan Family Code and the Algerian Family Code is incompatible with French public policy (Revue Trimestrielle de Droit civil, 2014-1, 94-95).

In both cases it was possible to apply Foreign law, corresponding to the nationality of both spouses (Morocco), as two bilateral covenants subscribed between France and Morocco and Algeria were in force, and allowed the implementation of the common national law, despite the entry into force of Regulation 1259/2000 on the law applicable to the dissolution of the marriage.

On the other hand, the notion of public policy of proximity is used, so that it is not accepted, for example, for the husband, of Moroccan nationality and resident in France, to file for dissolution of marriage under judicial supervision, if he could have requested it under grounds of disagreement. This case is incompatible with public policy, given that this person should have filed for divorce under a form of dissolution of marriage that exists in his national legislation and which is more compatible with those existing under French Law.

Spanish case law uses public policy when it comes to the revocable dissolution of marriage and, in particular, in a Judg. of the DGRN (General Directorate of Registries and Notaries) of October 26, 2006, it considers that this form of dissolution of marriage is incompatible with public policy, because it violates the principle of stability of the civil status of the person, as we are unable to find out if the person is divorced or not in this type of procedure for dissolution of marriage (BOE of December 13, 2006).

Also note the interesting judgement of the Court of Barcelona, dated April 6, 2000 (section 12), indicating that Moroccan Law is not inconsistent with public policy, but other than that followed by the Spanish legislature regarding the dissolution of marriage after the Law of 1981. The cases that were raised to the Spanish authorities in which the Moroccan Family Code is applied are already numerous, in accordance to the Art. 107 of the Civil Code, without being considered that this is a regulation incompatible with the public policy.

On the contrary, the recent sentences of the Provincial High Courts in Spain are a good example because they repeatedly consider that there is no such incompatibility neither in the case of dissolution of the marriage by the existence of disagreements (Art. 94 - 97 of the Family Code) neither by the causation of damage to the woman (Art. 98 of the Family Code). They are two different methods of dissolution of the marriage provided in the current Family Code of Morocco [SAP of Barcelona (section 12th), July $15^{\text {th }}$ (no. 304/2013)].

However, the entry into force of the Regulation 1259/2010 has changed this situation (see supra) by providing that, in case of absence of choice of applicable law, the required law to the common nationality of the spouse is applied in third place. Particularly, in this case, the Spanish judicial authorities apply the Spanish law as the law of the habitual residence [Art. 8, letter a)] [Provincial High Courts (SAP) of Barcelona (section 12th), December, 30th ( $\mathrm{n}^{\mathrm{a}}$ 571/2014) and Provincial High Courts (SAP) of Barcelona (section 12th), December, 11th (no. 1051/ 2013)].

The Art. 8 of said Regulation provides that: "Applicable law in the absence of a choice by the parties. In the absence of a choice pursuant to Article 5, divorce and legal separation shall be subject to the law of the State: 1) where the spouses are habitually resident at the time the court is seized; or, failing that 2) where the spouses were last habitually resident, provided that the period of residence did not end more than 1 year before the court was seized, in so far as one of the spouses still resides in that State at the time the court is seized; or, failing that 3) of which both spouses are nationals at the time the court is seized; or, failing that 4) where the court is seized".

Concerning the so-called "consolation dowry" ( $\left.m u t^{c} a\right)$ is also considered incompatible with the public policy, but, on the contrary, its equivalence with the alimony is established, existing in the common civil regulation 
[SAP (Provincial High Courts) of Gerona (section $1^{\text {a }}$ ), October, $2^{\text {nd }}$ (no. 413/2014), in interpretation of art. 84 of FC] However, it should be recalled that its function is to indemnify. We may not consider the anticipated impact of public policy, as the Judgement of the Provincial Court of Murcia no. 166/2003 (section 1) of May 12 suggests (Carrascosa González, 2004).

Finally, the Belgian case is interesting, which states that contrary to the notion of a secular State defended in France, in the formation of the Belgian State they have taken another model in which the secular is just another unit together with the religious and other forms of expression of society and its group. It is called "consociational political model", which leads to outcomes of interest in the field of Private International Law, to the extent that some situations are handled without taking into account the presence of the rules of conflict, and giving a direct response to the existence of a person of some of these connectives (including Muslims) (Christians, 2012).

\subsection{Compatibility of the Regulation of the Dowry with Ordre Public?}

The issue on compatibility in the regulation of the dowry with public policy in Islamic legal systems is of interest, and in this sense, it has been proposed to make use of the so-called "theory of data" to allow the consideration of the relevant Law corresponding to the origin of the person (even though the person has changed nationality, and holds that of the Forum) in such cases (Weller, 2014).

Use of the theory of data by the German jurisprudence cited above highlights the open mind that allows foreign legislation that has close ties with the matter, to be taken into account to give effect to the provisions of domestic substantive Law. In this sense, no only German judicial authorities do not consider the case to be of an unknown establishment, but they use the so-called "theory of data" (datum theory) to consider, for example, the existence in Iranian Law of clues that determine the amount corresponding to the woman in concept of dowry, in case this has not been determined at the time of marriage.

Or they even consider a reduction of the dowry, if the woman has requested the dissolution of marriage in exchange for a waiver of the dowry. However, there are a number of critical positions regarding this interpretation made by case law. Finally, we must also mention the decision of the BGH (German Supreme Court) of October 6, 2004, on the dissolution of marriage requested by the Iranian wife (Rauscher, 2005).

\subsection{Other Institutions of the Moroccan Family Law: Kafala}

Other issues of interest are also those arising from the possibility of using the procedure for family reunification in the case of EU Member State nationals under Directive 2004/38, in the case of children who have been taken in foster care in kafala. On this issue, the Communication from the Commission to the European Parliament and the Council of July 2, 2009, entitled "Guidance on aspects with a difficult transposition and application of Directive 2004/38”, states that children taken in temporary on foster care and parents exercising temporary care are entitled to avail of the rights conferred thereto by this directive based on the solidarity of the link established in each case [European Parliament Resolution of April 2, 2009, on the implementation of Directive 2004/38/EC on the right of citizens of the Union and their family members to move and reside freely within the territory of Member States (2008/2184 (INI)].

And in this sense, the judgement of the Court of Cassation of Italy (for the unification of the doctrine) of September 16, 2013 (no. 21108), believes that Italian nationals who wish to transfer the child taken in in kafala in Morocco to Italy may do so in accordance with the said Directive (Rivista di Diritto Internazionale Privato $e$ Processuale, 2014: $144 \mathrm{ff}$ ). It considers particularly that a resolution would now be out of place as the circumstances related to the case which led to the resource have changed Finally, we can also mentioned the hadana (Esteban, Ouald Ali, \& Saghir, 2008).

\subsection{Distribution of Widow's Pension in the Case of Polygamy?}

On the other hand, the issue of public policy has been also presented when the wives of the deceased apply for the widow's pension after his death in Spain. They are cases that have been resolved in very disparate ways by Tribunal Superior de Justicia (High Court of Justice) in Spain. In this regards, we may quote cases in which the pension to both widows is recognized (polygamous marriage), and other in which, on the other hand, the second marriage is considered null and, therefore, that pension could not be perceived. 
In the first sense suggested, specifically, the STSJ (High Court of Justice) of Galicia of April 2, 2002 (appeal no. 4795/1998) recognizes the widow's pension to both wives, of Senegalese nationality, of the deceased, of the same nationality, by employing — clearly - the notion of attenuate public policy. In particular, it is considered that public policy exception must act in a less rigid form (according to the jurisprudence of the Supreme Court) and, therefore, in the benefits context of the Social Security, it must be recognized the legal effects resulting from the marriage bond contracted abroad. However, the situation of polygamy does not allow qualifying for the full widow's pension for both widows, but it proceeds to its distribution.

The STSJ of Madrid of July 29, 2002 (appeal no. 3180/2002) also recognized the right of both widows of a Moroccan worker to receive a percentage of widow's pension. It was applicable the Convention on social security between Spain and Morocco of November 8, 1979 (BOE no. 245 of October 13, 1982). The Art. 23 provides that: "the widow's pension caused by a Moroccan worker will be distributed in equal parts and definitively between those who proved to be, according to the Moroccan legislation, beneficiaries of said pension".

However, the question of the concrete distribution of the pension arises, which must be done according to the Spanish legislation, i.e., calculated with respect to period of marital coexistence. And, in this case, it is the 50\% of the pension for each of the wives.

On the other hand, the STSJ of Catalonia, no. 5255/2003, of July 30, considers that, in the case of polygamous marriage contracted in Gambia, only is treated as the spouse the wife who with the deceased contracted the first marriage. The polygamy referred to a substantial element is rejected, which is considered of public policy, by deriving directly from the Constitution and the human rights conventions. The public policy model set out in the Constitution, as in the case of the European cultural environment and in Christian-rooted, determines the monogamy and none of the European Union countries accepts the celebration of a polygamous marriage (Juárez Pérez, 2012).

Finally, the STSJ of Valencia (no. 1821/2005) of June 6, 2005 adopts a similar position regarding the situation of two widows of the deceased, who contracted arranged marriage in the municipality of Tmixco (Mexican state of Morelos), without having been dissolved his previous marriage. Therefore, the second marriage is null and incompatible with public policy. It should be mentioned, in any event, the incoherence of this argument, as the nullity of a second marriage prevents the employment of the public policy exception to prevent that having implications in the forum. We must only allege the public policy when it is a valid relation, which cannot have implications in the forum as it is in contradiction to the higher principles or values of the regulation in a particular moment in time (present of the public policy).

\section{Final Considerations and Proposed Interpretation: The "Recognition Method"}

\subsection{General Considerations}

The progressive recognition of cultural diversity within the regulations and by international bodies (UNESCO) makes this diversity a value that must also be taken into account by the PIL system and it can lead to a renewal of regulation methods and techniques, which can also represent a renewal of the function of this system of rules. No longer does it only consist in giving a satisfactory response to international private situations, but also to channel (through its specific techniques and tools) values prevailing in the international community and ensuring the full effectiveness of human rights.

Along with this, the present day society, and in particular within the EU, has also evolved into a multicultural society in which people who coexist have not all been socialized in the same territory, there are also others who come from other territorial spaces and places in the world, whose usual place of residence is within the said European society (Regeiro \& Pérez Álvarez, 2014). Therefore, multicultural spaces have been created in places where previously there were only monolithic societies. This has forced us to conduct a process of adapting the techniques and tools traditionally used by the EU legislature to respond to such multicultural societies.

On the other hand, the foreign element may have become diffuse, to the extent that many people born abroad have acquired the nationality of the forum, but PIL questions still arise, and solutions must be provided, being this a situation of change of national law (Weller, 2014). Again, European case law is proof of such modification of personal status and of the need for the PIL system (European) to provide answers to such questions, highlighting most notably the efforts of the German case law cited above.

Now, another different question is that the successful implementation of a foreign regulation is achieved in all cases, given also the multiplicity of criteria that exist in each of the EU countries on the judicial function, which 
is highlighted when we speak of the Private International Law system (Bernard-Maugiron \& Dupret, 2014). To cite just a few examples, we should note the difficulties faced by the French authorities to determine the content of foreign Law (especially in the legislation of Islamic countries) and the ease with which German authorities apply it, for whom getting to know the content of the foreign legislations of any of these countries has no difficulty, focusing the issue on finding innovative solutions that allow granting a satisfactory solution in such cases.

On the other hand, we must quote the Belgian case, in which it has been considered that the constitution of this State allows the formation of different groups, which are on an equal footing, and, therefore, the secular nature of the State is just another one in conjunction with the religious outlook of the communities living therein (when compared with the French case) and, thus, the religious factor is considered within the regulation system, i.e., it has become internalized in the domestic substantive regulations, the PIL therefore not having to be applied.

Finally, Spanish decisions highlight the important ignorance that still exists on the content of such regulations and, in particular, on the Law of Morocco, despite the proximity of the two countries, not only geographically, but also on a personal level (Esteban de la Rosa, 2014b). However, the role of Private International Law, which is to promote the spatial continuity of decisions and to serve as a channel of communication between different regulations, must be fulfilled now more than ever.

Otherwise, on the one hand the creation of multicultural societies will not be enabled, and on the other hand, the recognition of European decisions in the country of origin of those migrating will be prevented. And therefore, a proposed interpretation of the whole PIL system is made according to the "recognition method" (see below).

\subsection{The "Recognition Method"}

The personal and family situations of Moroccan immigrants must be dealt with by the Spanish system of Private International Law, given that a foreign element is present. It is worth pointing out that currently a methodological renovation of Private International Law is taking place, especially after the second half of the twentieth century, where a collapse in the leadership previously enjoyed by certain States in the world order took place on the one hand and, on the other, the world became divided into symbolic units (sometimes in preference to people). As the doctrine points out, this divide took place once all aspiration to understand the sense of each of the "functional systems" which currently make up the world was lost. These systems interact as complex systems and do not allow predictions over the consequences (effects) that they may have over some aspects (Pérez Agote, 2005).

This renovation can also be linked to the current conformation of a micro-system within the legislation, the "social law of immigration", which effects Private International Law, obliging a reconsideration of its function and, above all, its traditional regulatory techniques, with the aim of verifying whether an adequate response to the needs of the people who migrate, in particular regarding their social integration, is offered (Gurvitch, 2005).

This question can also be found in the framework of a concrete political theory and/or philosophy, given that the system of Private International Law is no stranger to either the social demands or to the principle constructions and reflections on these demands. For this reason the "Theory of Recognition" offered by Charles Taylor (1993) seems to be the one to follow. This author refers to "the overwhelmingly monological tendency of the mainstream of modern philosophy" before cultural communities who wish to survive and who demand "recognition”, because they have realized that the identity of each person conforms to and is molded by, in part, their recognition or lack thereof (false recognition).

For this author, the notion of recognition is linked to the current concept of personal dignity (versus the concept of honour, abolished following the decadence of the hierarchical society) and is a vital human necessity. And, on the other hand, the identity "indicates something equivalent to the interpretation of who a person is and of its fundamental defining characteristics as a human being".

So that the current system of Private International Law can respond to the social question of immigration it must be-above all—a law which supports the needs of the people who migrate. It has been noted that "mass immigration", most importantly since the end of the last century, calls for a transformation of the system of PIL, which must give safe and simple responses (Mayer, 1977). From a different perspective, along the same lines, it is believed that the solutions must be efficient (Muir Watt., 2001). Its aim is to promote the spatial continuity of a person's family relationships, both in the country of origin and of habitual residence overseas. Thus, the "recognition method" depends on there being a general clause, which allows interpretation in accordance with the 
principle of social integration, in the system in question (Esteban de la Rosa, 2011).

The Spanish authorities ought to verify whether the relationship which they are to enter into the Forum would be recognised in the immigrant's country of origin and, if not, they must verify and consider the interests in play and the fairness of the result. That is, the authorities must examine the interests of those involved in order to decide, through the elimination, as far as possible, of difficulties concerning the recognition and enforcement of foreign judgements (in accordance with Spanish law) whether the foreign law must be applied to promote extraterritorial recognition of the (Spanish) decision in the immigrant's country of origin.

Note that the "recognition method" does not require a reform of Private International La, rather its interpretation in accordance with the principle of social integration when a private international situation related to immigration is submitted to the judicial authorities or other orders. Some cases in the Spanish case law can also be considered here, in which judicial authorities value the constitution of legal relations in the forum in response to the possibilities that have to be accredited in the immigrant's country of origin.

In this regard, the Sentence of the Appeal Court of Barcelona, no. 381/2006 (12th Section) of 8 June is noteworthy, as it considers the appeal filed and partially reverses the judgment at first instance, based on a different rationale law than that relied on by the appellant, in accordance with the Family Code (Aranzadi Database, JUR 2007\19193). The Appeal Court considers article 128 of the FC in order to assess whether the Spanish decision will be recognized in the country of origin of the former spouses, of Moroccan nationality (Esteban de la Rosa et al., 2007). If the FC of the dissolution of marriage is applied, the Spanish decision will be recognised in Morocco (art. 128 FC). Article 128 of the Family Code allows for the accreditation of foreign decisions over the dissolution of marriage, even if the Family Code was not applied, as long as the causes set out in Moroccan law were respected, in accordance with the case law interpretation (Loukili, 2010).

Finally, the recognition method represents a limit to the performance of peremptory norms (that protect fundamental rights), given that social integration is measured by Private International Law in the spatial continuity of an immigrant's family and personal relationships, both in their country of origin and in their country of habitual residence overseas.

\subsection{Ordre Public and Recognition Method}

Therefore, it can be said that within the framework of the progressive conformation of immigration and multicultural societies, the understanding of the role of public policy is also changing, inasmuch as it acts-in any case- once has been presented and known the contents of foreign law (and, therefore, it cannot be considered the early action of public policy), rejecting its application if it is contrary to the higher values or principles of regulations of the forum as they cannot be interpreted by taking into account the foreign cultural specificity (legal).

As stated by NASH (1999), "the challenge of the new 21st century remains to define the human rights in capable terms of upholding the principle of equality based on the recognition of diversity". And, with regard to the PIL system, the recognition method stands as a limit to the required application of the law of the forum, as the functional nature of the notion of integration, consisting in the spatial continuity of personal and family relationships of people who migrate (in countries of origin and residence abroad). In this regards, the doctrine refers to the public policy understood as concern of material justice (Gaudemet-Tallon, 2005).

The regulation of dissolution of the marriage in the current Family Code of Morocco (2004) could be given as an example. It is known that man and woman can use two different proceedings to request the dissolution of the marriage against the judicial authority, so that the first one can submit the request by talaq (as well as the woman in specific cases) and the second one by tatliq (and also the men on a supposed case). Moreover, the new Moroccan Family Code has made some relevant modifications that does not allow to considerate at the present time that said regulation is unlawful against the essential contents of the fundamental right to equality between man and woman (Art. 14 of the Spanish Constitution), as the Moroccan legislator has planned that the dissolution of the marriage also can be requested by both by the same way, allowing to take place without the woman has to meet more burdensome requirements.

Therefore, the Moroccan law must be applied when the conflict-of-law rule demands it, whereas it is incompatible with the Spanish public policy because, on the contrary, the essential contents of the right to equality is interpreted according to the (cultural) standards of the Islamic law, it is understandable that these differences have been maintained (Ounnir, 2008), that they are present in the form in which the dissolution of the marriage 
is conceived (Kreuzer, 2008). But this hasn’t stopped to include new criteria that allow requesting the dissolution of the marriage to both spouses through the same proceedings, and alleging the existence of disagreements (Art. 97 FC). On the other hand, if the Moroccan law is applied to the dissolution of the marriage, the Spanish decision is recognized in said country according to the Art. 128 of the Family Code.

And, finally, in any case, by stopping applying the foreign law, their specificities in order can be taken into consideration, for example, to promote the recognition of a decision in the country of origin of the immigrant (Esteban \& Saghir, 2009). i.e., even in the case of the action of the public policy have impeded the application of foreign law, the specificities of said regulation could be taken into account as a form of guardianship of free development of the personality and to promote the recognition of decisions in his/her country of origin (Esteban de la Rosa, 2009).

It's necessary to know the Private International Law system of said foreign country and to encourage, thus, the intercultural communication between the regulations of origin and those from the country of residence of the foreign immigrant. So the lack of appeal to the public policy exception (and its use, rather, as safeguard clause) allows the consultation of the foreign law-even when the essential content of a fundamental right is at stakeand the application when their contents are not incompatible with the fundamental right, what happens in this case, due the fact that the current regulation that provides the Family Code relation to the dissolution of the marriage cannot be considered, it is incompatible with the right to equality between man and woman.

Therefore, the public policy becomes a safeguard clause, i.e., a limit to the possibility that the forum accepts the cultural particularities or specificities of foreign law, because the sense in which said fundamental right is regulated does not allow, not only in the regulation of the forum, but in the international community. However, a mere difference regarding the content of foreign Law does not justify stopping applying, but it is necessary to know its interpretation to value what extent the scope of the fundamental right can infringe. And, in this sense, the doctrine refers to the secularization, specialization and flexibilization process that is experiencing the public policy at the present time (Aguilar Benítez de Lugo, 2001).

So there will be issues which cannot be regulated by the indicated in a foreign law regarding fundamental rights, but it is necessary to identify clearly—-firstly—-the essential contents of the fundamental rights (Quiñones Escámez, 1999). But, in that case, it is not about the action of public policy, but the mandatory rules of the forum, which regulate necessarily specific aspects of personal, familiar and living relationships of the immigrants. Thus, it can be said that in the immigration PIL gain in importance the rules of necessary implementation and not so much the notion of public policy.

However, the rules of necessary application can be projected on the private relationship (e.g., for the safeguard equality, understanding this to be the equal legal valuation of the differences), but, at the same time, the foreign Law can be applied to safeguard or promote the cultural identity, i.e., the free development of personality that, as is known, constitutes the active dimension of the right to dignity (Art. 10 of the Spanish Constitution), taking into consideration the specificities of the foreign law, in order to take place the recognition of the decision made by the authorities of the forum in the country of origin of the immigrant. And, even when the action of public policy does not allow the application of foreign Law claimed by the conflict-of-law rule.

For this reason, we must note that public policy has changed its role when it is about regulating some of the rights related to the (cultural) identity of the person. So, we must also note that public policy becomes a proceeding which modulates the possibility of accepting the cultural diversity, once the fundamental rights are not at stake, which constitute mandatory material rules.

\section{Conclusion}

The Spanish system of Private International Law is to serve as a "communication channel” between legislations which are beginning to coincide due to the new private international situations taking place in Spain, as a new foreign population begins to settle, in particular when it comes to female Moroccan immigrants (Esteban, 2014b). In these cases Moroccan family law may be applied or considered by the Spanish authorities, favouring thus the recognition of decisions taken in Morocco.

Finally, as a part of the gradual formation of multicultural societies, the understanding of the role of public policy is changing, to the extent that it acts once the content of the foreign law is apparent (an action in advance of public policy cannot be considered), dismissing application of the law if it is contrary to the higher values of the forum, and provides that it cannot be interpreted taking into account the foreign cultural specificity (legal). 


\section{References}

Abarca Junco, P. (2000). La regulación de la sociedad multicultural. Estatuto personal y multiculturalidad de la familia, Colex, Madrid, $16 \mathrm{ff}$.

Abarca Junco, P. (2005). Un ejemplo de materialización en el Derecho internacional privado español. La reforma del art. 107 del Código civil. En, Pacis Artes. Obra homenaje al Profesor Julio D. González Campos, Tomo II, EUROLEX, Madrid, $1096 \mathrm{ff}$.

Adam Muñoz, M a $^{\mathrm{a}}$ D. (2004). La modificación del art. 107 del Código civil y su incidencia en cuanto a la protección del derecho a la no discriminación por razón de sexo. Ámbitos. Revista de Estudios de Ciencias Sociales y Humanidades, $2^{\mathrm{a}}$ época, No. 11, esp. p. $81 \mathrm{ff}$.

Aguilar Benítez de Lugo, M. (2001). Estatuto personal y orden público en un contexto de creciente multiculturalidad. En, I. García Rodríguez (Ed.), Las minorías en una sociedad democrática y pluricultural (p. 332 ff). Alcalá de Henares: Universidad de Alcalá.

Bernard-Maugiron, N., \& Dupret, B. (dirs) (2014). Ordre public et Droit musulman de la famille en Europe et en Afrique du Nord. Bruxelles: Bruylant.

Carrascosa González, J. (2004). Crisis matrimoniales internacionales: Foro de necesidad y Derecho extranjero. Revista Española de Derecho Internacional, No. 1, 225 ff.

Carrillo Salcedo, J. A. (2005). Influencia de la noción de comunidad internacional en la naturaleza del Derecho internacional público. en, Pacis Artes. Obra homenaje al Profesor Julio D. González Campos, Tomo I, EUROLEX, Madrid, 175 ff.

Checa Martínez, M. (2011). Reconocimiento de la poligamia y del repudio islámicos en perspectiva comparada: A propósito de la Mudawwana marroquí. En J. V. Gavidia Sánchez (dir.), Inmigración, familia y Derecho (p. 245 ff). Madrid: Marcial Pons.

Christians, L. L. (2012). Les références belges à l’ordre public comme standard de régulation et révélateur de conflits de valeurs dans le statut des personnes musulmanes en dehors du Droit international privé: l'exemple belge. En, N. Bernard-Maugiron, \& B. Dupret (Dirs), Ordre public et Droit musulman de la famille en Europe et en Afrique du Nord (p. 463 ff). Bruxelles: Bruyllant.

Combalía, Z., Diago Diago, Mª P., \& González Varas, A. (coords.) (2011). Derecho islámico e interculturalidad. Madrid: Iustel.

Esteban de la Rosa, G. (2009). Inmigración y Derecho internacional privado. Madrid: Difusión Jurídica.

Esteban de la Rosa, G. (2014b). Implementation of the Moroccan Family Code by Spanish Authorities to Immigrant Women (Through the Recognition Method). Journal of Civil and Legal Sciences, 3, 1-9.

Esteban de la Rosa, G. (coord.) (2009). Nuevo Código de Familia marroquí y su aplicación en España. Madrid: Difusión.

Esteban de la Rosa, G. (dir.) (2010). La nueva Mudawwana marroquí: entre tradición y modernidad (Traducción comentada del Código de Familia de 2004). Sevilla: Junta de Andalucía.

Esteban de la Rosa, G. (2011). La integración social de los migrantes desde la perspectiva del sistema (español) de Derecho internacional privado. In J. Gavidia Sánchez (Ed.), Inmigración, Familia y Derecho (pp. 155 ff). Valencia: Marcial Pons.

Esteban de la Rosa, G., Ouald Ali, K., \& Saghir, T. (2007). Reconocimiento en Marruecos de la decisión españolas de divorcio? (Sobre la sentencia del JPI de Nules, de 30 de diciembre de 2005). Revista electrónica de la Facultad de Derecho de la Universidad de Granada, $1 \mathrm{ff}$.

Esteban de la Rosa, G., Ouald Ali, K., \& Saghir, T. (2008). Cap. 11. El derecho de hadana de la mujer marroquí con respecto a sus hijas e hijos en relación con el Derecho español. In Autores Varios (Ed.), La situación jurídico-familiar de la mujer marroquí en España (Vol. 25, pp. 269-290). Sevilla: Colec. Estudios de la Mujer, IAM.

Esteban de la Rosa, G., \& Saghir, T. (2009). Reconocimiento en Marruecos de las decisiones españolas de disolución del matrimonio (en el marco de las relaciones hispano-marroquíes). In Autores Varios (Ed.), Inmigración e integración de los extranjeros en España (pp. 477 ff). Madrid: Difusión Jurídica y temas de actualidad.

Esteban de la Rosa, G., \& Saghir, T. (2010). Reconocimiento de la igualdad entre hombre y mujer en la nueva mudawwana marroquí y su repercusión en la regulación de la disolución del matrimonio en Derecho internacional privado (español). In $\mathrm{M}^{\mathrm{a}}$ P. García Rubio, \& M $\mathrm{M}^{\mathrm{a}}$ del R. Valpuesta Fernández (dirs.), El levantamiento del velo: Las mujeres en el Derecho privado (pp. 151-177). Valencia: Tirant lo Blanch.

Foblets, $\mathrm{M}^{\mathrm{a}}$. C., \& Carlier, J. Y. (2005). Le Code marocain de la famille. Incidences au regard du droit international privé en Europe. Bruxelles: Bruylant.

Esteban de la Rosa, G. (2014a). Disolución del matrimonio en el Código de familia de Marruecos (2004) y derechos fundamentales de la mujer marroquí en España. In P. Laurenzo Copello, \& R. Durán Muñoz (coords.), Diversidad cultural, género y Derecho (pp. 483-513). Valencia: Tirant Lo Blanch. 
Gardeñes Santiago, M. (2012). L’application en Espagne du Droit des États de traditions islamique en ce qui concerne le mariage et les crises matrimoniales. Règles de conflit de lois et ordre public. In N. Bernard-Maugiron, \& B. Dupret (dirs), Ordre public et Droit musulman de la famille en Europe et en Afrique du Nord (pp. 279 ff). Bruxelles: Bruylant.

Gaudemet-Tallon, H. (2005). Cours général. Le pluralisme en Droit international privé: Richesses et faiblesses (Le funambule et l'arc-en-ciel). Recueil des Cours, 312, $275 \mathrm{ff}$.

Gruber, U. P. (2012). Scheidung auf Europäisch—Die Rom III-Verordnung. Praxis des internationalen Privat- und Verfahrensrechts, 5, $381 \mathrm{ff}$.

Gurvitch, G. (2005). La idea del Derecho social. Granada: Comares.

Hammje, P. (1997). Droits fondamentaux et ordre public. Revue Critique de Droit International privé, $1 \mathrm{ff}$.

Helms, T. (2014). Konkludente Wahl des auf die Ehescheidung andwendbaren Rechts? Praxis des internationalen Privatund Verfahrensrechts, 4, $334 \mathrm{ff}$.

Jayme, E. (1992). Diritto di famiglia, società multiculturale e nuovi sviluppi del Diritto Internazionale Privato. Rivista di Diritto Internazionale Privato e Processuale, 295-304.

Juárez Pérez, P. (2012). Jurisdicción española y poligamia islámica: ¿un matrimonio forzoso? Revista Electrónica de Estudios Internacionales, $1 \mathrm{ff}$. (Online)

Kreuzer, K. (2008). International Instruments on Human Rights and Shariah Law. In Vers des nouveaux équilibres entre ordres juridiques. Mélanges en l'honneur de Hélème Gaudemet-Tallon (pp. 343 ff). Paris: Dalloz.

Loukili, M. (2010). El reconocimiento de decisiones en Marruecos en el ámbito del Derecho de familia. In: AAVV (Ed.), Inmigración e integración de los inmigrantes desde una perspectiva hispano-francesa en el contexto de las actuales políticas comunitarias sobre inmigración (pp. 285-304). Granada: Comares.

Mayer, D. (1977). Evolution du statut de la famille en droit international privé. Journal du Droit International, $453 \mathrm{ff}$.

Monéger, F. (2014). Le Code de la famille marocain de 2004 devant la Cour de Cassation. Revue Critique de Droit International Privé, 2, $427 \mathrm{ff}$.

Muir Watt, H. (2001). Le modèles familiaux á l'épreuve de la mondialisation (Aspects de Droit international privé). In A. L. Calvo Caravaca, \& J. L. Iriarte ángel (Eds.), Mundialización y familia (pp. 12 ff). Madrid: Colex.

Ortiz Vidal, Mª D. (2014). El repudio en el Código de familia de Marruecos y la aplicación del Derecho marroquí en la Unión Europea. Cuadernos de Derecho transnacional, $201 \mathrm{ff}$.

Ouald Ali, K. (2011). La disolución del matrimonio en el Derecho marroquí. In J. V. Gavidia Sánchez (dir.), Inmigración, familia y Derecho (pp. 289 ff). Madrid: Marcial Pons.

Ouhida, J. (2009). Del Código del Estatuto personal y de las sucesiones al actual Código de familia de Marruecos de 2004. In G. Esteban de la Rosa (dir.), Traducción del Código de familia de Marruecos (pp. 17-42). Jaén: Imprenta Blanca.

Ounnir, A. (2008). La reconnaissance et l'exécution des jugements étrangers au Maroc. In Autores Varios (Ed.), Estudios e Informes sobre la Inmigración extranjera en la provincia de Jaén (2005-2006) (pp. 451-469). Observatorio Permanente sobre la Inmigración, Granada: Comares.

Pérez Agote, A. (2005). En la era global: Ruptura de ecuaciones y dicotomías de la modernidad. In: A. Ariño Villarroya (Ed.), Las encrucijadas de la diversidad cultural (pp. 313 ff). Madrid: CIS.

Petit, M. (2012). Génesis y evolución de los conceptos cultura y diversidad desde los acuerdos de la OMC (1994) hasta la Convención de la UNESCO sobre diversidad cultural (2005). Revista de Estudios Políticos, No.156, 209 ff.

Quiñones Escámez, A. (1999). El estatuto personal de los inmigrantes musulmanes en Europa: Exclusión, alternancia y coordinación de sistemas.In XVII Jornadas de Profesores de Derecho internacional y Relaciones Internacionales (1997) (pp. $181 \mathrm{ff}$ ). Madrid: BOE.

Quiñones Escámez, A. (2004). La reception du nouveau Code de la famille marocain (Moudawana, 2004) en Europe. Rivista di Diritto Internazionale Privato et Proccesuale, No. 3, 887-888.

Rauscher, T. H. (2005). Iranischrechtliche Scheidung auf Antrag der Ehefrau vor deutschen Gerichten (zu BGH, 6.10.2004). Praxis des internationalen Privat- und Verfahrensrechts, 4, $313 \mathrm{ff}$.

Regeiro García, Ma. T., \& Pérez Álvarez, S. (dirs) (2014). Gestión de la diversidad cultural en las sociedades contemporáneas. Valencia: Tirant lo Blanch.

Rodríguez Benot, A. (2002). Tráfico externo, Derecho de familia y multiculturalidad en el Derecho español. In A. Rodríguez Benot (dir.), La multiculturalidad, especial referencia al Islam (pp. 15 ff). Col. Cuadernos de Derecho judicial, VIII-2002, Madrid: CGPJ.

Taylor, C. H. (1993). El multiculturalismo y la política del reconocimiento. México: Fondo de Cultura Económica.

Weller, M. P. H. (2014). Die neue Mobilitätsanknüpfung im Internationalen Familienrechr-Abfederung des personalstatutenwechsels über di Datumtheorie. Praxis des internationalen Privat- und Verfahrensrechts, 3, 225 ff. 